Original Article

\title{
Description of Pudica wandiquei n. sp. (Heligmonellidae: Pudicinae), a nematode found infecting Proechimys simonsi (Rodentia: Echimyidae) in the Brazilian Amazon
}

\author{
Descrição de Pudica wandiquei n. sp. (Heligmonellidae: Pudicinae), nematódeo \\ encontrado infectando Proechimys simonsi (Rodentia: Echimyidae) na Amazônia \\ brasileira
}

\author{
B. E. Andrade-Silva ${ }^{\mathrm{a}, \mathrm{b} *}$ (D), G. S. Costa ${ }^{\mathrm{a}, \mathrm{c}}$ (1) and A. Maldonado Júnior ${ }^{\mathrm{a}}$ (D) \\ aFundação Oswaldo Cruz - FIOCRUZ, Instituto Oswaldo Cruz - IOC, Laboratório de Biologia e Parasitologia de Mamíferos Silvestres \\ Reservatórios, Rio de Janeiro, RJ, Brasil \\ bFundação Oswaldo Cruz - FIOCRUZ, Instituto Oswaldo Cruz - IOC, Programa de Pós-graduação em Biologia Parasitária, Rio de Janeiro, RJ, Brasil \\ 'Fundação Centro Universitário Estadual da Zona Oeste - UEZO, Rio de Janeiro, RJ, Brasil
}

\begin{abstract}
A new species of nematode parasite of the subfamily Pudicinae (Heligmosomoidea: Heligmonellidae) is described from the small intestine of Proechimys simonsi (Rodentia: Echimyidae) from the locality of Nova Cintra in the municpality of Rodrigues Alves, Acre state, Brazil. The genus Pudica includes 15 species parasites of Neotropical rodents of the families Caviidae, Ctenomyidae, Dasyproctidae, Echimyidae, Erethizontidae, and Myocastoridae. Four species of this nematode were found parasitizing three different species rodents of the genus Proechimys in the Amazon biome. Pudica wandiquei $\mathrm{n}$. sp. can be differentiated from all other Pudica species by the distance between the ends of rays 6 and 8 and the 1-3-1 pattern of the caudal bursa in both lobes.
\end{abstract}

Keywords: spiny rats, Nematoda, Acre State, Amazon rainforest.

\begin{abstract}
Resumo
Uma nova espécie de nematódeo da subfamília Pudicinae (Heligmosomoidea: Heligmonellidae) é descrito parasitando o intestino delgado de Proechimys simonsi (Rodentia: Echimyidae) em Nova Cintra, município de Rodrigues Alves, Estado do Acre, Brasil. O gênero Pudica inclui 15 espécies parasitas de roedores Neotropicais das famílias: Caviidae, Ctenomyidae, Dasyproctidae, Echimyidae, Erethizontidae e Myocastoridae. Destas, quatro espécies de nematódeos foram encontradas parasitando três diferentes espécies do roedor Proechimys no bioma Amazônia. Pudica wandiquei n. sp. é diferente das outras espécies de Pudica pela distância entre os raios 6 e 8 e pelo tipo da bolsa caudal, que é 1-3-1 em ambos os lados.
\end{abstract}

Palavras-chave: rato de espinho, Nematoda, Estado do Acre, floresta Amazônica.

\section{Introduction}

The parasitic nematodes of the genus Pudica Travassos and Darriba, 1929 are members of the subfamily Pudicinae Skrjabin and Schikhobalova, 1952, family Heligmonellidae Skrjabin and Schikhobalova, 1952. A prominent characteristic of these nematodes is the presence of ventral comaretes on at least the proximal portion of the body. At the present time, 15 Pudica species are known to infect Neotropical rodents of six families - the Caviidae, Ctenomyidae, Dasyproctidae, Echimyidae, Erethizontidae, and Myocastoridae (Durette-Desset and Justine, 1991; Durette-Desset et al., 2017; Serrano et al., 2019).
The echimyid rodents of the genus Proechimys Allen, 1899 have been reported as reservoirs of parasitic zoonoses and a potential threat to public health (Cordeiro et al., 2015a). A total of 22 Proechimys species have been described from localities in Central and South America (Patton and Leite, 2015), and four Pudica species have been found parasitizing three of these species - Proechimys longicaudatus (Rengger, 1830), Proechimys semispinosus (Tomes, 1860), and Proechimys roberti Thomas, 1901 - in the Amazon biome (Cordeiro et al., 2015b). 
The Amazon biome is the world's largest tropical forest, a region of high temperatures and abundant rainfall, with an extremely diverse biota, which provide ideal conditions for the evolution of an equally diverse parasitic fauna. However, ongoing anthropogenic impacts in the Amazon has provoked the widespread loss of habitats, and many parasite species, even before they have been discovered (Penna et al., 2009; Olival et al., 2017; Fernandes et al., 2018).

More and more studies on conservation biology are becoming necessary, and investigations of helminth fauna can help us in monitoring parasites, including in hosts that are threatened with extinction (Gomes et al., 2019; Souza et al., 2021).

The present study describes a new species of the genus Pudica found infecting the small intestine of Proechimys simonsi Thomas, 1900 at the locality of Nova Cintra, in the municipality of Rodrigues Alves, Acre state, Brazil.

\section{Materials and Methods}

\subsection{Study site}

Ten rodent specimens were collected during a five-day survey in south western Amazonia in May 2016. The specimens were collected in the municipality of Rodrigues Alves, Acre state, Brazil (7.8149S, 72.6799W), using a Tomahawk ${ }^{\circledR}$ Live Trap (USA) baited with a mixture of peanut butter, banana, oats, and bacon. All necessary biosafety procedures were respected during the handling of the specimens and the collection of the biological samples (Lemos and D'Andrea, 2014). The rodents were anesthetized and euthanized for the extraction of helminths and other biological samples following Costa-Neto et al. (2016). Voucher specimens (rodents) were deposited in the scientific collection of the UFRJ National Museum (Museu Nacional, Universidade Federal do Rio de Janeiro). All capture and handling procedures followed the guidelines of the Ethics Committee for the Experimental Use of Animals (CEUA) of the Oswaldo Cruz Institute - IOC (Instituto Oswaldo $\mathrm{Cruz}$ ), under permit L-39/14. The collection of animal specimens was authorized by the Chico Mendes Institute for Biodiversity Conservation - ICMBio (Instituto Chico Mendes de Conservação da Biodiversidade) of the Brazilian federal government, through license number 13373.

\subsection{Analysis of the helminths}

The worms were washed in a $0.85 \%$ saline $(\mathrm{NaCl})$ solution and stored in 70\% ethanol. For light microscopy, the nematodes were clarified in lactophenol ( $40 \%$ glycerin, $20 \%$ lactic acid, and $20 \%$ phenol in q.s. $100 \mathrm{~mL}$ of water). The specimens were drawn using a camera lucida attached to a Nikon Eclipse E200MVR light microscope (Nikon Corporation, Tokyo, Japan). The morphological structures were measured using a Zeiss Axio Cam HRC digital imaging system (Zeiss, Germany), with the Axio Vision Rel accessory software, version 4.7. All measurements are given in micrometers. The measurements of holotypes and allotypes are followed by the ranger between brackets, and mean and standard deviation between parentheses of the paratypes. The nematodes were identified following Anderson et al.
(2009), Vicente et al. (1997) and Durette-Desset et al. (2017). The holotype, allotype, and paratypes were deposited in the helminthological collection of the Oswaldo Cruz Institute (CHIOC) in Rio de Janeiro.

\section{Results}

Heligmosomoidea Travassos, 1914

Heligmonellidae Leiper, 1912

Pudicinae (Skrjabin and Schikobalova, 1952) Durette-Desset, 1971

Pudica wandiquei n. sp. Figures 1 and 2.

\subsection{Description}

General: Very small nematode, body coiled irregularly with two coils in both sexes. Round deirids close to excretory pore, both located halfway between nerve ring and esophagus-intestine junction. Cephalic vesicle present (Figure 1A). Oral opening triangular, surrounded by small, thick ring. Four cephalic papillae, four external labial papillae, and two amphids in apical view (Figure 1B).

Synlophe: Cuticle with longitudinal and uninterrupted ridges in both sexes. Ridges posterior to cephalic vesicle, extending close to copulatory bursa in male and anus in female. Females with eight ridges (careen, three dorsal, two ventral and one comarete), careen more developed

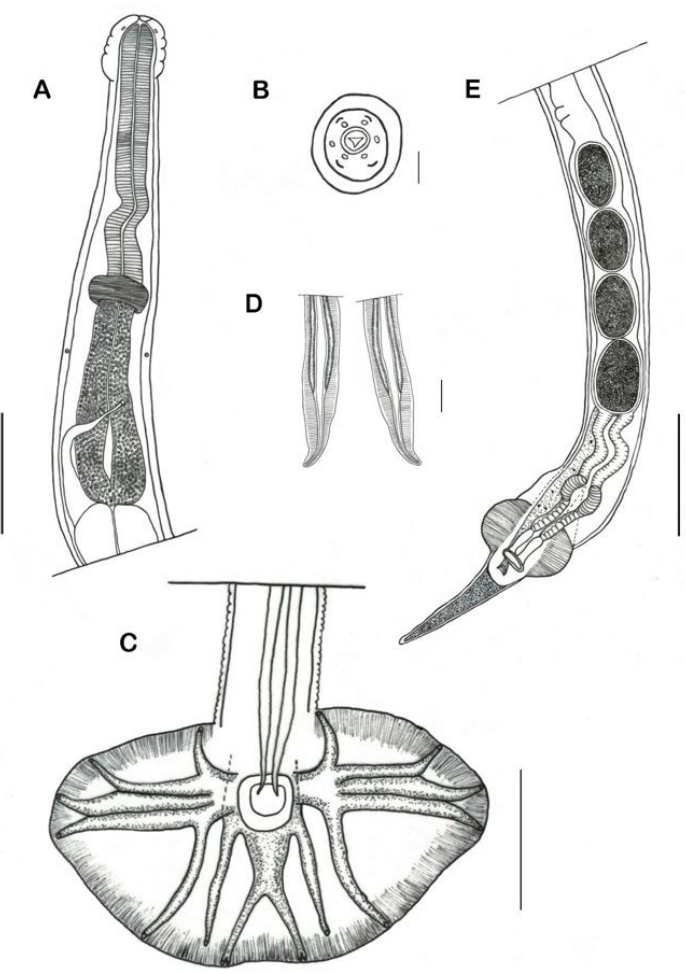

Figure 1. Pudica wandiquei n. sp. (A) anterior extremity, ventral view; (B) head, apical view; (C) Male, ventral view, posterior extremity; (D) tips of spicules; (E) Female, ventral view, posterior extremity. Scale bars in A and C50 $\mu \mathrm{m}$; B and D10 $\mu \mathrm{m}$; E $100 \mu \mathrm{m}$. 
and comarete larger than other ridges in mid-body. Careen poorly developed at infundibulum, with ridges of equal size. Axis of orientation is from right to left in both sexes (Figure 2A, B, C). In male with eight ridges (careen, three dorsal, two ventral and one comarete), varying in size along body with careen more developed in the first third and comarete slightly larger than other ridges. In the median portion, more developed comarete; in posterior third, ridges decrease progressively in size (Figure 2D, E, F).

\subsection{Male (holotype and nine paratypes)}

Body 2,110 [2,000-2,430 (2,120 \pm 120$)]$ long and 60 [40-70 (60 \pm 10$)]$ wide at mid point. Cephalic vesicle 30 [25-31 (28 \pm 2.5$)]$ long and $20[18-27(23 \pm 2.5)]$ wide. Nerve ring, deirids and excretory pore located at 90 [90-120 (105 \pm 15$)], 130$ [80-185 (148 \pm 59$)]$, 170 [160-200 (176 \pm 13$)]$ from apex, respectively. Oesophagus 240 [200-262 (236 \pm 16$)]$ long. Bursa subsymmetrical, type 1-3-1, in both lobes (Figure 1C). Ray 2 curved ventrally and shorter than ray 3. Rays 3, 4, 5 grouped, rays 6 long diverging at the base of the trunk, all reaching edge of caudal bursa. Rays 4 and 5 diverging at the distal ends. Rays 8 smaller than dorsal ray, arising from proximal portion of dorsal ray. Dorsal ray divided in to two branches the middle of the trunk. Each branch divided into two sub-branches, ray 9 (external) and ray 10 (internal). Filiform alate spicules, long, 350 [335-369 (352 \pm 32 )], with sharp tip extremity (Figure 1D). Spicule: body length
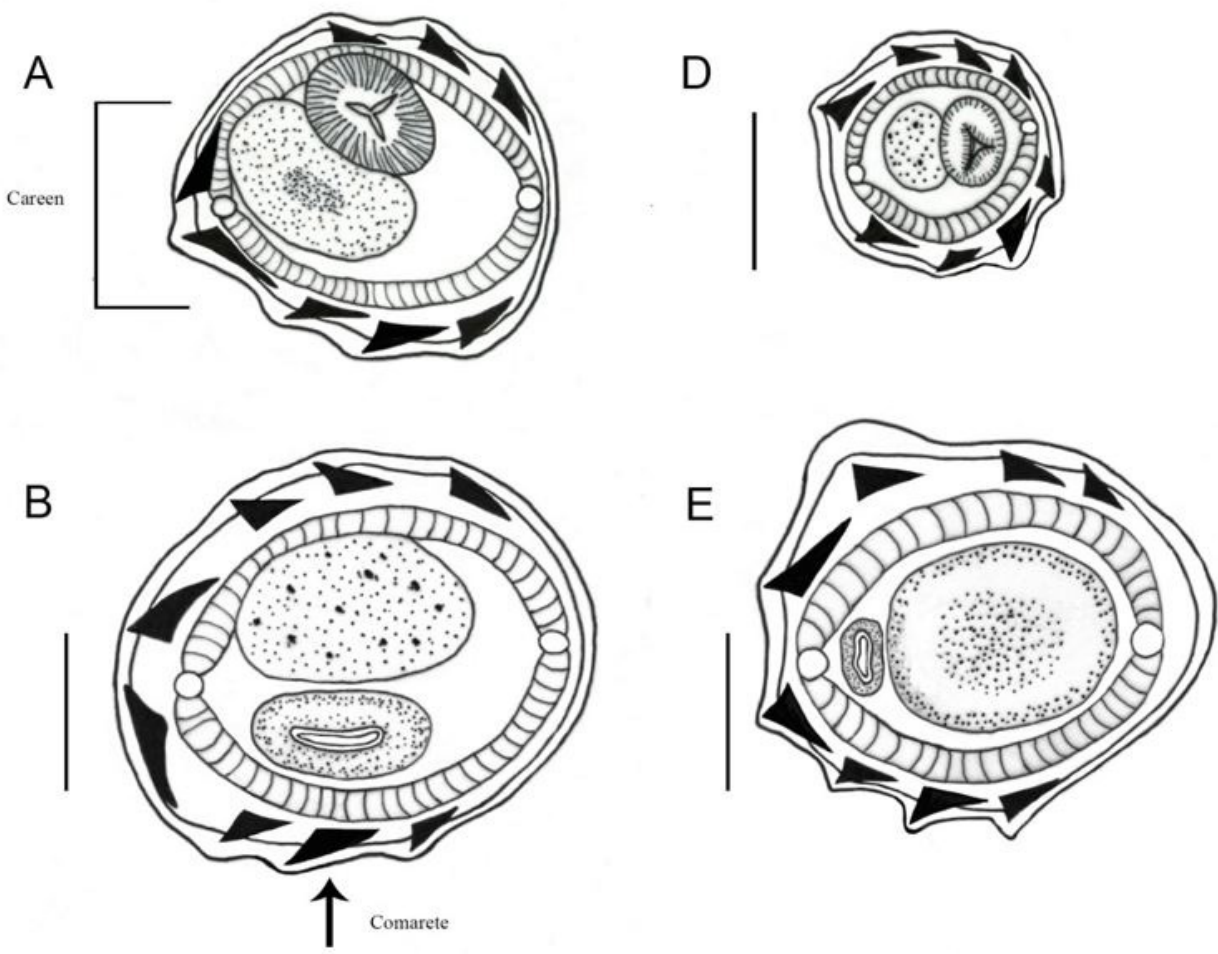

C

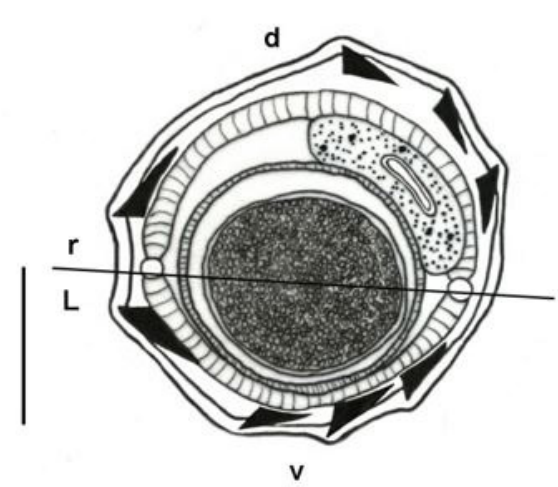

F

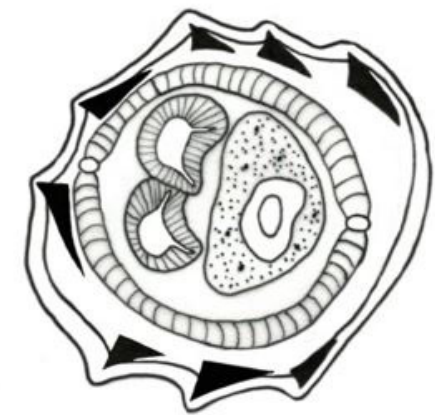

Figure 2. Pudica wandiquei n. sp. Synlophe in transverse sections of the body. A, B, C Female. (A) at oesophago-intestinal junction; (B) at mid-body; (C) at level of uterus. D, E, F Male. (D) at oesophago-intestinal junction; (E) at mid-body; (F) at level of spicules. Scale bars $25 \mu \mathrm{m}$. Abbreviations: $\mathrm{d}=$ dorsal; $\mathrm{v}=$ ventral; $\mathrm{L}=$ left; $\mathrm{r}=$ right. 
ratio $16.6 \%$. Genital cone rounded. Papillae 0 and 7 not observed. Gubernaculum absent.

\subsection{Female (allotype and nine paratypes)}

Body 2,390 [2,070-2,620 (2,290 \pm 180$)] \mathrm{mm}$ long and 65 [50-90 $(60 \pm 20)]$ wide at mid point. Cephalic vesicle 31 [27-32 (29 \pm 1.69$)]$ long and 24 [22-27(23 \pm 1.7$)]$ wide. Nerve ring, deirids and excretory pore located at 87 [82-92 (87 \pm 7$)]$, 124 [113-135 (127 \pm 15$)]$ and 153 [130-177 (153 \pm 33$)]$, from apex, respectively. Oesophagus 245 [212-277 (244 \pm 19$)]$ long. Reproductive tract monodelphic. Vulva situated at 156 [120-158 (139 \pm 16$)]$ from caudal extremity. Vagina vera 49 [25-90 (54 \pm 24$)]$ long, vestibule 56 [35-85 (55 \pm 21$)]$ long, sphincter 37 [27-44 (34 \pm 6$)]$ long and 49 [43-51 $(47 \pm 8)]$ wide, and infundibulum 112 [40-120 (68 \pm 27$)]$ long. Uterus 158 [133-201 (161 \pm 25$)]$ long, containing 1-4 eggs, 78 [62-80 (66 \pm 7$)]$ long and 25 [22-27 (23 \pm 1$)]$ wide. Uterus: body length $7.03 \%$. Tail thin and conical, 110 [80-130 (100 \pm 20$)]$ long. Posterior extremity with two latero-ventral vulvar alae parallel to body (right and left), tapering past vulva (Figure 1E).

\subsection{Taxonomic summary}

Type host: Proechimys simonsi Thomas, 1900 (Rodentia, Echimyidae)

Site of infection: Small intestine.

Type locality: Nova Cintra (7.8149S, 72.6799W), municipality of Rodrigues Alves, Acre state, Brazil.

Prevalence: $50 \%$ (5 of the 10 rodents collected).

Mean intensity: 130.6 (653 helminths in the 5 infected rodents).

Mean abundance: 65.3 (653 helminths in the 10 rodents collected).

Deposition of type specimens: Helminthological collection of the Oswaldo Cruz Institute in Rio de Janeiro (CHIOC). Holotype accession number CHIOC 38992a (male); allotype accession number CHIOC 38992b (female); paratype accession numbers CHIOC 38992c (1 male and 1 female). All specimens are preserved in 70\% ethanol.

Etymology: The species epithet is a tribute to José Wandique Fraga da Costa, a valuable and long-serving contributor to the Laboratory of the Biology and Parasitology of Wild Mammal Reservoirs (LABPMR) at the Oswaldo Cruz Institute in Rio de Janeiro, Brazil.

\section{Discussion}

Caviomorph rodents were the first to occupy the South American continent. Throughout its evolutionary history, it has undergone successive dispersion processes forming several taxa, with the Echimyidae family being considered the most diverse family of the infraorder Hystricognathi, occupying several ecological niches, distributed in different Neotropical regions with several species acting as a helminth host and reservoir of zoonosis (Patterson and Wood, 1982; Huchon and Douzery, 2001; Fabre et al., 2016; Eler et al., 2020).

Up to now, 15 Pudica species have been described, of which, seven are parasites of rodents of the family
Echimyidae, Four of these species (P. minima, P. evandroi, $P$. tenua, and $P$. ginsburgi) were found parasitizing three different echimyid rodents of the genus Proechimys ( $P$. roberti, $P$. semispinosus and $P$. longicaudatus) in the Amazon biome (Serrano et al., 2019). However, it is not yet known what the evolutionary relationship between the helminths parasites and these rodents.

According to Durette-Desset et al. (2017) the genus Pudica is characterized by a synlophe with a careen, made up of two continuous ridges, three to five continuous dorsal and ventral ridges, and at least two ventral comaretes; and a bursa of the 2-2-1 or 1-3-1 type, with the dorsal ray divided in its anterior half. In the present study, the presence of careen, three dorsal ridges, two ventral ridges, one ventral comarete, and a caudal bursa of 1-3-1 type, jointly with the absence of a gubernaculum, supported the inclusion of the helminth specimens collected in the municipality of Rodrigues Alves in the genus Pudica.

Compared with its congeners, Pudica wandiquei n. sp. has the same number of ridges found in Pudica gonosoma Cassone and Durette-Desset, 1991, that is, eight continuous ridges in both sexes (exclusive to these two species) therefore distinguishing itself from all other species of the genus. However, P. gonosoma can be differentiated from Pudica wandiquei $\mathrm{n}$. sp. by the configuration of the caudal bursa. While Pudica wandiquei n. sp. presents a 1-3-1 pattern in both lobes, $P$. gonosoma has a 1-4 pattern, as described by Durette-Desset and Digiani (2012) when conducting a study on the caudal bursa in the Heligmonellidae. In addition the presence of a bursa membrane connecting the base of the rays 6 in P. gonosoma is not observed in Pudica wandiquei n. sp. Furthermore, female P. gonosoma specimens present a cuticular post vulvar expansion, structure not observed in Pudica wandiquei n. sp.

The pattern of the bursa observed in the new species resembles that found in Pudica cattani Digiani et al. 2017, P. evandroi (Travassos, 1937), and Pudica cercomysi (Durette-Desset and Tchéprakoff, 1969), but in general according to the classification key of Serrano et al. (2019) Pudica wandiquei n. sp. can be distinguished from these three species by the distance between the ends of rays 6 and 8, which are close in P. cattani, P. evandroi, and P. cercomysi and separate in Pudica wandiquei n. sp.

Furthermore, these three species differ from the new species by the following features: P. cattani has lateral and dorsal rays robust but not hypertrophied, rays 4 curved anteriorly, rays 6 curved posteriorly, and the dorsal lobe moderately developed; $P$. evandroi is characterized by the strong thickening of the lateral trunks of rays 3-5 and the trunk of the dorsal ray, and $P$. cercomysi has a dorsal ray dividing at proximal quarter of length, rays 6 and 8 parallel and similar in size. All these characters contrast markedly with Pudica wandiquei $\mathrm{n}$. sp. which has the rays 2 to 6 reaching the edge of the caudal bursa, trunk of the dorsal ray not hypertrophied and rays 8 relatively short.

In conclusion, these diagnostic characters support the classification of the nematodes found infecting Proechimys simonsi in southwestern Amazonia as a new species, Pudica wandiquei n. sp., the sixteenth species of the genus described to date. Moreover, the study of biodiversity in the tropics, especially in the Amazon, is important 
and urgent, given the accelerated degree of loss of this biome by anthropic action. Knowing biodiversity and the relationship between species generates subsidies for conservation actions.

\section{Acknowledgements}

We would like to thank Dr. Paulo Sérgio D’Andrea for his collaboration with IFAC (Instituto Federal do Acre), which permitted the collection of the hosts and Dr. Sócrates F. da Costa Neto for collecting the helminths. We are grateful to CAPES (Coordenação de Aperfeiçoamento de Pessoal de Nível Superior) and FIOCRUZ (Fundação Oswaldo Cruz) for providing scholarships.

\section{References}

ANDERSON, R.C., CHABAUD, A.G. and WILLMOTT, S., 2009. Keys to the nematode parasites of vertebrates: archival volume. Wallingford: $C A B$ International.

CORDEIRO, H., MELO JÚNIOR, F.T.V., MALDONADO JUNIOR, A. and SANTOS, J.N.D., 2015a. Spirura carajaensis n. sp. (Nematoda: Spiruridae), parasite of Proechimys roberti Thomas, 1901 (Rodentia: Echimyidae) from Brazilian Amazon. Helminthologia, vol. 52, no. 1, pp. 28-33. http://dx.doi. org/10.1515/helmin-2015-0007.

CORDEIRO, H., MELO, F.T., FURTADO, A.P., GIESE, E.G., MALDONADO JÚNIOR, A. and SANTOS, J.N., 2015b. Squamasnema amazonica n. gen. n. sp. (Heligmonellinae): a new parasite of Proechimys roberti (Rodentia: Echimyidae) in the Brazilian Amazon. Acta Tropica, vol. 148, pp. 46-50. http://dx.doi.org/10.1016/j. actatropica.2015.04.005. PMid:25910627.

COSTA NETO, S.F., OLIVEIRA SIMÕES, R., MOTA, É.M., VAL VILELA, R., LOPES TORRES, E.J., SANTOS BARBOSA, H., GENTILE, R. and MALDONADO JUNIOR, A., 2016. Lungworm Heterostrongylus heterostrongylus Travassos, 1925 from the black-eared opossum in South America: morphologic, histopathological and phylogenetic aspects.Veterinary Parasitology, vol. 228, pp. 144-152. http://dx.doi.org/10.1016/j.vetpar.2016.08.018. PMid:27692317.

DURETTE-DESSET, M.C. and DIGIANI, M.C., 2012. The caudal bursa in the Heligmonellidae (Nematoda: Trichostrongylina): characterisation and hypothesis on its evolution.Parasite, vol. 19, no. 1, pp. 3-18. http://dx.doi.org/10.1051/parasite/2012191003. PMid:22314236.

DURETTE-DESSET, M.C. and JUSTINE, J.L., 1991. A cladistic analysis of the genera in the subfamily Pudicinae (Nematoda, Trichostrongyloidea, Heligmonellidae).InternationalJournal of Parasitology, vol. 21, no. 5, pp. 579-587. http://dx.doi. org/10.1016/0020-7519(91)90063-D. PMid:1743854.

DURETTE-DESSET, M.C., KILANI, M., GEFFARD-KURIYAMA, D. and DIGIANI, M.C., 2017. Critical revision of the Heligmonellidae (Nematoda: Trichostrongylina: Heligmosomoidea).Paris: Muséum National d'Histoire Naturelle, 290 p. Mémoires du Muséum National d'Histoire Naturelle, no. 211.

ELER, E.S., SILVA, C.E.F., SILVA, M.N.F. and FELDBERG, E., 2020. New karyotype records for the genus Proechimys (Rodentia: Echimyidae) from Brazilian Amazonia.Genetics and Molecular Biology, vol. 43, no. 3, e20190093. http://dx.doi. org/10.1590/1678-4685-gmb-2019-0093. PMid:32484848.
FABRE, P.H., UPHAM, N.S., EMMONS, L.H., JUSTY, F., LEITE, Y.L., CAROLINA LOSS, A., ORLANDO, L., TILAK, M.K., PATTERSON, B.D. and DOUZERY, E.J., 2016. Mitogenomic phylogeny, diversification, and biogeography of South American spiny rats.Molecular Biology and Evolution, vol. 1, no. 34, suppl. 3, pp. 613-633. http://dx.doi. org/10.1093/molbev/msw261. PMid:28025278.

FERNANDES, J., GUTERRES, A., DE OLIVEIRA, R.C., CHAMBERLAIN, J., LEWANDOWSKI, K., TEIXEIRA, B.R., COELHO, T.A., CRISÓSTOMO, C.F., BONVICINO, C.R., D'ANDREA, P.S., HEWSON, R. and LEMOS, E.R.S., 2018. Xapuri virus, a novel mammarenavirus: natural reassortment and increased diversity between New World viruses.Emerging Microbes E Infections, vol. 7, no. 1, pp. 120. http://dx.doi.org/10.1038/s41426-018-0119-9. PMid:29959319.

GOMES, A.P.N., MALDONADO JÚNIOR, A., BIANCHI, R.C., SOUZA, J.G.R., D’ANDREA, P.S., GOMPPER, M.E. and OLIFIERS, N., 2019. Variation in the prevalence and abundance of acanthocephalans in brown-nosed coatis Nasua nasua and crab-eating foxes Cerdocyon thous in the Brazilian Pantanal.Brazilian Journal of Biology = Revista Brasileira de Biologia, vol. 79, no. 3, pp. 533-542. http://dx.doi.org/10.1590/1519-6984.187881. PMid:30540104.

HUCHON, D. and DOUZERY, E., 2001. From the Old World to the New World: a molecular chronicle of the phylogeny and biogeography of hystricognath rodents.Molecular Phylogenetics and Evolution, vol. 20, no. 2, pp. 238-251. http://dx.doi. org/10.1006/mpev.2001.0961.PMid:11476632.

LEMOS, E.R.S. and D'ANDREA, P.S., 2014. Trabalho com animais silvestres: procedimentos, riscos e biossegurança.Rio de Janeiro: Fiocruz, 180 p. http://dx.doi.org/10.7476/9786557080658.

OLIVAL, K.J., HOSSEINI, P.R., ZAMBRANA-TORRELIO, C., ROSS, N., BOGICH, T.L. and DASZAK, P., 2017. Host and viral traits predict zoonotic spillover from mammals.Nature, vol. 546, no. 7660, pp. 646-650. http://dx.doi.org/10.1038/nature22975. PMid:28636590.

PATTERSON, B. and WOOD, A.E., 1982. Rodents from the Desead an Oligocene of Bolivia and the relationships of the Caviomorpha. Bulletim of Museum of Comparative Zoology, vol. 149, pp. 371-543.

PATTON, J.L. and LEITE, R.N., 2015. Genus Proechimys. JA. Allen, 1899. In: J.L.PATTON, U. F. J.PARDIÑAS and G.D'ELÍA, eds. Mammals of South America.Illinois:University of Chicago Press, vol. 2, Rodentspp, 950-989.

PENNA, G., PINTO, L.F., SORANZ, D. and GLATT, R., 2009. High incidence of diseases endemic to the amazon region of Brazil, 2001-2006.Emerging Infectious Diseases, vol. 15, no. 4, pp. 626632. http://dx.doi.org/10.3201/eid1504.081329. PMid:19331758.

SERRANO, P.C., DURETTE-DESSET, M.C. and DIGIANI, M.C., 2019. Pudicinae (Nematoda) coparasitic in Proechimys roberti (Rodentia: Echimyidae) from the Brazilian Amazonia: description of a new species of Pudica, redescription of Pudica evandroi (Travassos) and updated key to the species of the genus.Anais da Academia Brasileira de Ciências, vol. 91, no. 4, e20180714. http://dx.doi.org/10.1590/0001-3765201920180714. PMid:31721918.

SOUZA, M.V., CHAVES, S.A.M. and IÑIGUEZ, A.M., 2021. New observations from the intestinal fauna of Kerodon rupestris (Wied, 1820) (Rodentia, Cavidae), Brazil: a checklist spanning 30,000 years of parasitism.Brazilian Journal of Biology = Revista Brasileira de Biologia, vol. 81, no. 4, pp. 989-998. http://dx.doi. org/10.1590/1519-6984.232838. PMid:33111930.

VICENTE, J.J., RODRIGUES, H.O., GOMES, D.C. and PINTO, R.M., 1997. Nematóides do Brasil. Parte V; Nematóides de Mamíferos.Revista Brasileira de Zoologia, vol. 14, suppl. 1, pp. 1-452. http://dx.doi. org/10.1590/S0101-81751997000500001. 